\title{
Optimizing Omnibus Law in Indonesia: A Legal Enquiry on the Use of Artificial Intelligence for Legislative Drafting
}

\author{
Zaki Priambudi* \\ University of Jember, Indonesia \\ Namira Hilda Papuani \\ University of Jember, Indonesia
}

\section{Ramdhan Prawira Mulya Iskandar \\ University of Jember, Indonesia}

\begin{abstract}
The omnibus law model is often regarded as a practical solution to harmonize and synchronize statutory regulations. In practice, the application of this model tends to be pragmatic and less democratic. This paper aimed to analyze the essential considerations and challenges of implementing the omnibus law model in Indonesia and the further relevance of applying Artificial Intelligence (AI) in the legislation. By combining doctrinal and socio-legal research, this paper demonstrated the potential for AI in optimizing the omnibus law model legislation. The results of this study indicated that AI could not immediately replace the role of legislative institutions and only acts as a tool and not as a determinant in the legislative process. There were two AI features that could assist legislative bodies in designing the omnibus law model. They were document review as a construction scanner for legislation and predictive analytics as a prediction system. Both could help legislative bodies in optimizing the omnibus law model, which tended to have a high complexity level. As a follow-up, it was expected that the government could create a special institution that focused on optimizing AI-based legislation.
\end{abstract}

KEYWORDS: Omnibus Law, Artificial Intelligence, Legislation, Public Participation.

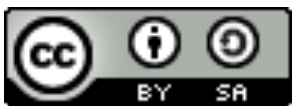

\section{HOW TO CITE:}

Priambudi, Zaki et al., "Optimizing Omnibus Law in Indonesia: A Legal Enquiry on the Use of Artificial Intelligence for Legislative Drafting" (2021) 2:1 Indonesian Journal of Law and Society 78-104.

Submitted: 05/01/2021 Reviewed: 13/01/2021 Revised: 15/02/2021 Accepted: 17/02/2021

\footnotetext{
* Corresponding authors' e-mail: zakypriambudi@gmail.com
} 


\section{INTRODUCTION}

Economic growth requires simpler laws and regulations and the omnibus law becomes an alternative in the agenda of harmonizing laws and regulations to support the investment climate. Due to the large number of contents in the omnibus law model but the lack of supporting facilities and mechanisms, most public aspirations are often not accommodated in the design process. ${ }^{1}$ Whereas in democracies, public participation is crucial. ${ }^{2}$ The participation becomes an indicator in law-making for people's interests. ${ }^{3}$

This paper aimed to analyze the basis for the government's rationalization in choosing the omnibus law model to simplify laws and regulations and their problems. Then, it proceeded with an analysis of several Artificial Intelligence (AI) features expected to overcome these problems. Especially, it dealt with the follow-up to implement AI for the omnibus law legislation. Several similar studies discussed the use of AI in legislation. The first was the research conducted by Eka NAM Sihombing and Muhammad Yusrizal Adi Syaputra. It examined the probability of AI replacing the organs that formed regional regulations juridically and theoretically. ${ }^{4}$ This research concluded that AI could not automatically replace the organs that formed regional regulations due to taking decisions requiring a more humane touch. The second observation examined the use of AI in making laws. ${ }^{5}$ It showed AI having a role in forecasting and ranking matters that later required regulation by legislation. Thus, it is necessary to analyze the probability of

1 Deni Umbara, Jum Hermanto \& Franky Ariyadi, "Community Pro-Contra Project for the Presence of the Omnibus Law Bill in Legal Sociology Perspective" (2020) 4: 2 Legal Standing: Jurnal Ilmu Hukum 168-173.

2 Eko Noer Kristiyanto, "The Urgency of the Omnibus Law in Accelerating Regulatory Reform in a Progressive Legal Perspective" (2020) 20: 2 De Jure Legal Research Journal 233-244 at 233-234.

3 Muhammad Fakhrur Razy \& Muhammad Fedryansyah, "Conflict of Civil Society Movement and Government in the Process of Drafting the Omnibus Law Bill" (2020) 2: 2 Collaborative Journal of Conflict Resolution 74-85 at 80-81.

4 Eka NAM Sihombing \& Muhammad Yusrizal Adi Syaputra, "Implementation of the Use of Artificial Intelligence in Forming Regional Regulations" (2020) 14: 3 Scientific Journal of Legal Policy 419-434 at 419.

5 Paulus Wisnu Yudoprakoso, "Artificial Intelligence as a Tool for the Formulation of Laws in Facing the Industrial Revolution 4.0 in Indonesia" (2019) 1: 1 Indonesian Legal Symposium 450-461 at 450. 
implementing $\mathrm{AI}$ in legislation to answer the problems faced in designing the omnibus law model. An analysis of the use of AI in legal practice and the use of information technology in legislation in other countries considers a need to update the method of legislation. It is because conventional legislative methods are very time-consuming. ${ }^{6}$

This study analyzed the essential considerations for selecting the omnibus law model in Indonesia, the challenges of implementing the omnibus law model, and the further relevance of using AI to the omnibus law legislation. This paper is organized as follows. The first part will discuss the primary considerations for implementing Indonesia's omnibus law model after the introductory section and research methods. The second part will invite readers to analyze the challenges of implementing the omnibus law in Indonesia. Then, the third part will discuss the relevance of implementing $\mathrm{AI}$ in optimizing omnibus law legislation. The last section will conclude with the following-up ideas regarding the issue.

\section{METHODS}

This paper combined doctrinal and socio-legal research. Doctrinal research examined policies regarding omnibus law and AI's application relating to the formation of laws both at the national and international levels. ${ }^{7}$ Meanwhile, socio-legal research was used to analyze regulations and their relationship with other disciplines and other factors that influence law enforcement. ${ }^{8}$

6 Wulf A Kaal, "Dynamic Regulation for Innovation" (2016) Perspectives in Law, Business \& Innovation (Mark Fenwick, Wulf A Kaal, Toshiyuki Kono \& Erik PM Vermeulen eds), New York Springer (2016) 16-22 at 18.

7 The research was carried out by looking at existing laws, followed by considering several issues affecting the law and the political practice of the underlying law. The purpose of this method can lead researchers to initiate a change in the law. Wing Hong Chui \& Mike McConville, Research Methods for Law (Edinburgh University Press Edinburgh, 2007) at 20-21.

8 This research focused on the relationship between law and society as an interconnected social phenomenon. Socio-legal research was characterized by a prescriptive model that offers an alternative to the prevailing regulations in society. Ibid at 40-41. 


\section{BASIC CONSIDERATIONS TO THE APPLICATION OF OMNIBUS LAW IN INDONESIA}

The law as a social engineering tool is expected to provide certainty and answers to humans' problems. ${ }^{9}$ In providing certainty and justice, the law needs to adapt to the times' increasingly complex dynamics. ${ }^{10}$ One of them is economic problems, which result in decreased population productivity. Indonesia is facing stagnating economic growth in recent years. It is evidenced by Indonesia's national economic growth's stagnation for the last four years, which only reached 5 percent. ${ }^{11}$ This percentage is still far from the target set by the government. ${ }^{12}$ The slow pace of the economy led to an increase in the unemployment rate, which reached 7.05 million people per year. Meanwhile, Indonesia generates 2 million workers every year, and Indonesia must prepare to respond to the demographic bonus starting from 2020 to $2035 .^{13}$

The National Development Planning Agency (Bappenas) stated that the national economic growth target is 6 percent from 2020 to 2040. This figure estimates that every 1 percent economic growth can absorb 460,000 workers. ${ }^{14}$ It requires the government to spur the economy as optimally as possible to reach 6 percent to open jobs to accommodate the 2 million workforces each year and the existing 7.05 million unemployed people.

To achieve this target, the government needs at least an investment figure of IDR 4,800 trillion to estimate that every 1 percent of national economic

9 H Yacob Djasmani, "Law as a Social Engineering Tool in Legal Practice in Indonesia" (2011) 40: 3 Legal Problems 365-374 at 365.

10 Suwardi Sagama, "Analysis of the Concept of Justice, Legal Certainty and Benefit in Environmental Management" (2016) 15: 1 Mazahib 20-41 at 22.

11 Central Bureau of Statistics, Indonesian National Income 2015-2019 (2020) at 78.

12 The government is targeting 7 to 8 percent in the 2014-2019 National Medium Term Development Plan. Ministry of National Development Planning / National Development Planning Agency, "National Medium Term Development Plan 20152019"(2019) National Medium Term Development Plan 2020-2024 at 4-11.

13 Central Bureau of Statistics, "Indonesian Youth Statistics 2019" (2019) Jakarta: Statistics Indonesia at 4.

${ }^{14}$ Central Bureau of Statistics, "August 2020: Open Unemployment Rate (TPT) of 7.07 percent", (2020), online: <https://www.bps.go.id/pressrelease/2020/11/05/1673/ august-2020 - open-unemployment-rate-tpt-by-7-07-percent.html . 
growth requires an IDR 800 trillion investment. A large amount of investment requires the government to make extra efforts in inviting foreign investors. ${ }^{15}$ However, Indonesia's competitiveness is relatively low when compared to other countries, ${ }^{16}$ one of the causes is the long bureaucratic chain caused by overlapping laws and regulations. At least 8,945 regulations were issued from October 2014 to October 2018, starting from the central to regional levels. On average, there are at least six regulations published every day. ${ }^{17}$ Even though President Joko Widodo has evaluated the current bureaucratic chain several times, it focuses more on processes than tangible results relevant to more responsive government services. ${ }^{18}$

According to Bappenas, overlapping laws and regulations resulted in Indonesia's low competitiveness amid global competition. ${ }^{19}$ It is reflected in the results of the Doing Business study released by the World Bank. Indonesia is ranked 73rd in 2019 in terms of licensing. ${ }^{20}$ Singapore was in second place, Malaysia 12th, Taiwan 15th, Thailand 16th, Brunei Darussalam 66th, and Vietnam 70th. ${ }^{21}$ From these data, it concludes that Indonesia is still lagging compared to neighboring countries regarding the ease of obtaining business permits.

Regulatory disharmony caused by overlapping laws and regulations is a significant factor in hampering the accelerated economic program's execution. As a result, various public services access, particularly efforts to open job opportunities in business convenience facilities, are hampered. In

15 National Development Planning Agency, "Ministry of National Development Planning," online: <https://www.bappenas.go.id/id/berita-dan-siaran-pers/rencanapembangunan-jangka-menengah-nasional-rpjmn-2020 -2024 / >

16 In 2019 Indonesia was ranked 50th, down five places from 2018. Klaus Schwab, "The Global Competitiveness Report 2019" (2019) World Economic Forum at 282.

17 Center for Indonesian Law and Policy Studies (PSHK), Study of regulatory reform in Indonesia: issues and strategies for handling them (2019) at 64-65.

18 Kompas, "Complete Text of President Joko Widodo's Speech in the Inauguration of the 2019-2024 Period - JEO Kompas.com", online: <https://nasional.kompas.com/ jeo/naskah-lLengkap-pidato-presiden-joko-widodo-dalam-inauguration-period2019-2024>.

19 Indonesian Center for Law and Policy Studies (PSHK), supra note 17 at 8-10.

20 World Bank (Washington, District of Columbia), ed, Doing business 2020, Doing business (Washington: World Bank Group, 2019) at 4.

21 Ibid at 4. 
this case, the government has homework to synchronize and harmonize laws and regulations. However, this process, apart from having procedural obstacles, also took a long time. ${ }^{22}$

The Indonesian Center for Law and Policy Studies (PSHK) found five fundamental problems in the statutory system that need to be corrected. ${ }^{23}$ First, planning laws and regulations that are not in sync with development planning. It has significant implications for the relationship between the center and the regions, which causes regional autonomy to be ineffective. For example, in mid-2016, the Central Government canceled 3,143 Regional Regulations, which were considered to be hampering regional economic growth, lengthening bureaucratic channels, and hindering investment and ease of doing business. ${ }^{24}$ Second, improper charge material. Many substance problems can be regulated by one statutory product. However, they are regulated in several legislative products. ${ }^{25}$

Third, there is hyper-regulation. From October 2014 to October 2018, there were at least 8,945 regulations issued at the national level, starting from Laws, Government Regulations, Presidential Regulations, and Ministerial Regulations. In sum, there are at least six regulations published every day. ${ }^{26}$ Fourth, there is no monitoring and evaluation mechanism. Only using one perspective of a ministry or agency can create a ministry monitoring and evaluation process that only partially and only prioritizes certain institutions' interests. It is feared that such a situation will foster a sectoral ego attitude not to solve the problem. ${ }^{27}$

Fifth, functional and institutional problems. The absence of an agency with full authority to manage regulations nationally means that the authority to

22 Kristiyanto, supra note 2 at 236.

${ }^{23}$ Indonesian Center for Law and Policy Studies (PSHK), supra note 17 at 100-101.

24 Ministry of Home Affairs of the Republic of Indonesia, "Kemendagri Officially Announces 3,143 Perda Canceled", (June 21 2016), online:anno-3-143-perda Cabinet Secretariat of the Republic of Indonesia <https://setkab.go.id/kemendagri-resmi-whatcanceled/>.

25 Indonesian Center for Law and Policy Studies (PSHK), supra note 17 at 34-35.

26 Ibid at 64-65.

27 Ibid at 94. 
formulate policies and formulate these regulations is spread over the ministries or agencies. ${ }^{28}$

To overcome these various problems, PSHK recommends several steps. ${ }^{29}$ First, integration of statutory planning systems with development planning. Second, tightening harmonization and synchronization in controlling the process of forming the legislation. Third, optimization of legislative planning that is more measurable and relevant to needs. Fourth, institutionalizing the monitoring and evaluation function in the statutory regulation system. Fifth, integrating functions in the statutory system through institutional arrangement and strengthening the system. In responding to the above problems, this paper finds that the omnibus law is a logical solution because it is practical and comprehensive. Its substance can regulate laws and regulations that were previously split into one extensive regulation. ${ }^{30}$ Louis Massicotte argues that the omnibus law model can save time and shorten the legislative process. It is because legislative agencies do not need to change many laws as a whole but simply through one bill that contains many material changes from various laws. ${ }^{31}$ Relevant to this view, Glen S. Krutz said that the omnibus law's application could prevent legal uncertainty after the formation of a law that only includes one material so that it has the potential to conflict with other laws. ${ }^{32}$

The omnibus law model can help legislative institutions reach an agreement, shorten forming a law (undang-undang) and avoid political deadlock. This model also increases legislation efficiency and increases productivity in the legislative process, facilitating efforts to harmonize laws and regulations. ${ }^{33}$

28 Ministry of National Development Planning, "National Strategy for Regulatory Reform: Realizing Simple and Orderly Regulations" (2015) Ministry of National Development Planning / National Development Planning Agency at 45.

29 Center for Indonesian Law and Policy Studies (PSHK), supra note 17 at 3.

30 Bayu Dwi Anggono, "Omnibus Law as a Law Formation Technique: Adoption Opportunities and Challenges in the Indonesian Legislative System" (2020) 9: 1 Rechtsvinding at 26.

31 Louis Massicotte, "Omnibus Law in Theory and Practice" (2013) 36: 1 Canadian Parliamentary Review at 65.

32 Glen S Krutz \& Samuel C Patterson, Hitching a ride: Omnibus legislating in the US Congress (Ohio State University Press, 2001) at 161.

33 Anggono, supra note 30 at 7. 
By harmonizing laws and regulations, Indonesia is expected to invite more foreign and domestic investors to open businesses in Indonesia to open more jobs. This is per the 1945 Constitution, one of which is the principle of benefit. Law enforcement does not result in harm but benefits to society, the nation, and the state. ${ }^{34}$

The omnibus law model is also not contradictory and remains subject to Law Number 12 of 2011 on Legislative Drafting as amended to Law Number 15 of 2019. The omnibus law will be positioned under Article 7(1) letter c. ${ }^{35}$ Then in substance, it is also under Article 10(1) letter b. ${ }^{36}$

There are at least four benefits from the application of the omnibus law model in Indonesia. ${ }^{37}$ First, shorten the implementation of the legislative process. Second, to prevent deadlock in the deliberation of the bill in the House of Representatives. Third, the cost-efficiency of the legislative process. Fourth, the harmonization of laws and regulations is maintained.

The omnibus law model is a rational solution to overcoming overlapping laws and regulations in Indonesia. Moreover, Indonesia is facing unprecedented global challenges, such as technological and economic disruption. The urgent situation made the government select the omnibus law model. The peak of the omnibus law's application is expected to optimize efforts to accelerate legal reform in Indonesia, especially those related to harmonizing various cross-sectoral regulations at the central to regional levels.

\section{THE CHALLENGES OF IMPLEMENTING THE OMNIBUS LAW IN INDONESIA}

The omnibus law model is not a perfect system. It is not free from various criticisms. Aaron Wherry said that the Omnibus Law model is a reflection

34 Mahfud MD, "Constitution and Law in Controversy over Issues" (2010) Rajawali Pers, Jakarta at 384.

35 The omnibus law's position will still be under the Basic Law, but its position will be higher than other legislation types.

${ }^{36}$ The article is outlined, "... an order of a law to be regulated by law".

37 Anggono, supra note 30 at 35. 
of pragmatic legal practices ${ }^{38}$ and less democratic because the omnibus law will change the norms of laws from various political initiatives. ${ }^{39}$ Forming a law using the omnibus law is currently not regulated by Law No. 12 of 2011. It causes bias in the design mechanism, which has the potential to result in violating the principles of forming the legislation.

The synchronization of the philosophical, sociological, and juridical foundations in the omnibus law also poses its challenges, considering that each law tends to only have one subject, in contrast to the omnibus law contains many subjects. This has resulted in not being proportionally absorbed by the philosophical, sociological, and juridical foundations because each law has problems with different approaches. As part of the considerations that must be contained in a law, philosophical, sociological, and juridical foundations have an essential meaning. A law can be implemented under the principles of statutory regulations. These considerations indicate consideration of the effectiveness of the law. ${ }^{40}$ Besides, the process of hearing opinions will also decrease in quantity because the legislative body has a limited deadline. In line with that, Sinclair and Smith also said that the omnibus law model's application would change the principle of deliberative democracy. This is because the omnibus law model often accelerates the drafting process compared to the draft bill's usual drafting. ${ }^{41}$ It reflects from the Job Creation Bill's relatively fast deliberation process, in which the House of Representatives only needs 64 sessions to discuss 1,203 Articles. ${ }^{42}$

38 Prioritizing results and ignoring applicable procedures.

39 Mirza Satria Buana, "Measuring the Concept of Omnibus Law and Consolidation Law to Harmonize Indonesian Legislation: A Comparative Approach to Constitutional Law" (2017) at 312.

40 Maria Farida Indrati, Responding to Omnibus Law as the Sweep of the Universe Law (Djokosoetono Research Center and Department of State Administrative Law, Universitas Indonesia, 2020).

41 Krutz \& Patterson, supra note 32 at 141.

42 Cantika Adinda Putri, "DPR is Top! 1,200 Articles of Omnibus Law Completed Through 64 Meetings ", online:finished-lewat-64 news <https://www.cnbcindonesia. com/news/20201006154706-4-192288/dpr-top-1200-pasal-omnibus-law-sel-times meetings $>$. 
In this case, the draft law also received several criticisms and protests from labor groups, academics, and students. ${ }^{43}$ It was caused by drafting the Job Creation Bill, deemed not accountable and participatory. ${ }^{44}$ It is marked by the public's difficulty in accessing the draft and academic text of the Job Creation Bill. ${ }^{45}$ The rapid drafting strategy amid the inadequacy of the omnibus law model's mechanism made the House of Representatives unable to comprehensively review the bill, which had implications for reduced public participation. ${ }^{46}$ Even though this is, of course, contrary to the provisions of the legislation-making mechanism. ${ }^{47}$

Public participation in the formation of laws cannot be contested because it becomes the main spirit of democracy. Public participation reflects People's Sovereignty and a Democratic State guaranteed by the Constitution, particularly Article 1(2) of the 1945 Constitution. Moreover, Indonesia already has several laws requiring public participation in the formation of laws, such as Public Information Disclosure Law, Public Services Law, Spatial Planning Law, and the Legislative Drafting Law. Even the Legislative Drafting Law specifically regulates public participation in the formation of laws. ${ }^{48}$

The violation of public participation in the making of laws does not only injure democracy but will result in legally defective products and materially. The hasty drafting process resulted in the loss of the principles of prudence,

43 Razy \& Fedryansyah, supra note 3 at 76. Muhammad Bahrul Ulum, "Indonesian Democracy and Political Parties After Twenty Years of Reformation: A Contextual Analysis" (2020) 10:1 Indonesia Law Review at 35.

${ }^{44}$ Komnas HAM, "Komnas HAM: Unaccountable and Participatory Omnibus Law Formulation," (January 31, 2020), online: National Human Rights Commission KOMNAS HAM <https://www.komnasham.go.id/index.php/news /2020/1/31/1319/ komnas-ham-penyusunan-omnibus-law-tidak-akuntabel-and-participatif.html .

45 Razy \& Fedryansyah, supra note 3 at 80-81.

46 Rizal Irvan Amin, "Omnibus Law Between Desiderata and Reality" (2020) 15: 2 Journal of Ocean Justice Law 190-209 at 199.

47 Article 94 of Law No.12 of 2011 outlines, "To facilitate the public in providing input orally and/or in writing as referred to in paragraph (1), every Draft Laws and Regulations must be easily accessible to the public".

48 Kristiyanto, supra note 2 at 234. 
thoroughness, and openness. It can lead to the creation of a bad law product and has the potential to harm society. ${ }^{49}$

In practice, the omnibus law model's application also often bypasses several stages of the statutory regulation-making procedure. ${ }^{50}$ In Indonesia, this happened during the drafting process of the Job Creation Bill. At that time, the House of Representatives was caught overstepping several procedures in the provisions of the House of Representatives Regulation Number 1 of 2020 on Rules of Procedure. At that time, the head of the working meeting (Raker) immediately formed a working committee without discussing the bill's material according to the Problem Inventory List (DIM) sent by each faction. It violated the provisions of Article 151(1), ${ }^{51}$ Article 154(1), ${ }^{52}$ and Article 156(1) the House of Representatives' Rules. ${ }^{53}$ Because, at that time, it was not all factions were ready to submit DIM. ${ }^{54}$

Given the various problems above, the supporting facilities for designing the omnibus law model in Indonesia are not ideal, appearing to impose a process in the middle of an inappropriate law formation mechanism. In addition to the amendments to the Legislative Drafting Law, the legislative body needs a supporting facility that can function in the long term. Therefore, this paper proposes using AI to improve effectiveness and efficiency in the omnibus law legislation. It is entirely rational because, in practice, $\mathrm{AI}$ is commonly used

49 Fahmi Ramadhan Firdaus, "Prevention of Legislation Corruption through Strengthening Public Participation in the Process of Forming a Law"(2020) 17: 3 Indonesian Legislation Journal 282-293 at 290.

50 Vincent Suriadinata, "Formulation of Laws in the Investment Sector: Study of the Formation of Omnibus Law in Indonesia" (2019) 4: 1 Reflection on Law: Journal of Legal Studies 115-132 at 121-122.

51 The Working Committee's draft bill's discussion occurs after a Working Meeting between the commissions, joint commissions, the Legislative Body, the Special Committee, the Budget Agency, and the ministers representing the President.

52 A Working Meeting was held to discuss all the bill's contents according to the problem inventory list (DIM) of each faction in the House of Representatives or the Board of Regional Representatives if the draft law discussed relates to its authority.

53 A General Hearing Meeting was held to obtain input on the draft law being discussed.

54 Indonesian Center for Law \& Policy Studies, "Discussion of the Omnibus Bill on Job Creation Directly to the Panja: Trimmed Participation, Regulations Willed", (20 April 2020), online: pshk.or.id <https://pshk.or.id/publikasi / discussion-omnibuscopyright-work-direct-to-panja-participation-trimmed-order-cutting-edge / $>$. 
as a detection and prediction system, ${ }^{55}$ then $\mathrm{AI}$ can help legislative bodies and the public to evaluate the available data in drafting laws and assessing the implications of future legal rules. ${ }^{56}$

\section{RELEVANCE OF THE IMPLEMENTATION OF ARTIFICIAL INTELLIGENCE FOR THE OMNIBUS LAW DRAFTING}

\section{A. The Use of Information Technology in Legislations in Other Countries}

It is unrealistic for legislative bodies to accept most of the public's input into modeling the omnibus law. Given that the omnibus law model is identical to the number of articles and subjects that tend to be more than ordinary laws. It is a logical consequence of the limited time for discussion and the urgent need for the implications and harmonization of laws and regulations. One alternative that can be considered is to use information technology in the field of legislation.

In other countries, the use of information technology in the making of legislation has been widely adopted. The Netherlands has adopted InternetBased Consultation since 2009. The Ministry of Justice and Security initiated the adoption by publishing the bill that is being drafted, including the bill's implications on the website for 12 weeks, and anyone can give their aspirations to the bill. ${ }^{57}$ The model is also run by Australia, Denmark, Canada, and the UK. ${ }^{58}$ It is deemed necessary to be implemented in Indonesia. Thus, this paper proposes the use of $\mathrm{AI}$ in legislation. One of the reasons is that $\mathrm{AI}$ can be integrated with various public services, making it easier for legislative bodies to obtain data-based considerations in a shorter

55 Bernard Marr, "How AI And Machine Learning Are Transforming Law Firms And The Legal Sector," online: Forbes <https://www.forbes.com/sites/bernardmarr/2018/ 05/23/how-ai-and-machine-learning-are-transforming-law-firms-and-the-legalsector / > .

56 Kaal, supra note 6 at 13.

57 Organization For Economic Co-operation and Development (OECD), "Better Regulation in the Netherlands" (2009) European Commission 112 at 64.

58 Akhmad Adi Purawan, "Corruption of Legislation in the Formation of Legislative Regulations" (2014) 3: 3 Rechtsvinding: Media of National Law Development 347363 at 361. 
and more accurate so that the law products produced are under the community's needs. ${ }^{59}$

In addition, Indonesia can apply Internet-Based Consultation as it has been implemented in the Netherlands. ${ }^{60}$ The website can be integrated with AI so that data analysis of public aspirations can be carried out in a more comprehensive, which has implications for increased public participation in legislation. It certainly increases the essence of democracy, namely the high level of public participation in law and policymaking. ${ }^{61}$

\section{B. AI's Role in Law Enforcement in Other Countries}

China and America are two examples of countries that present technological trends in the legal field. In China, models of the Smart Court system have emerged. Several typical applications include case analysis types, automated judgments, standard-setting of evidence, and systems for profiling judges. ${ }^{62}$

China has adopted and implemented several national strategies to deal with technological developments in the Industrial Revolution 4.0, especially AI. Under the Central Government's command, examples of programs that have proven successful include the Case Management System in Guiyang, the Intelligent Criminal Case Handling System in Shanghai, the Internet Court in Hangzhou, and the Smart Court in Suzhou. ${ }^{63}$

In America, the AI technology applied in the legal field is very welcome by lawyers. Some of the application areas include legal research, predictive

59 Slava Jankin Mikhaylov, Marc Esteve \& Averill Campion, “Artificial intelligence for the public sector: opportunities and challenges of cross-sector collaboration" (2018) 376: 2128 Philosophical Transactions of the Royal Society A: Mathematical, Physical and Engineering Sciences, online: <https://royalsocietypublishing.org/doi/full/ 10.1098/rsta.2017.0357> at 2-3.

60 Organization For Economic Co-operation and Development (OECD), supra note 57 at 64.

61 Frank Fagan \& Saul Levmore, "The Impact of Artificial Intelligence on Rules, Standards, and Judicial Discretion" (2019) 93 Southern California Law Review 1 at 1.

${ }^{62}$ Ran Wang, "Legal technology in contemporary USA and China” (2020) 39 Computer Law \& Security Review at 2.

63 Ibid. 
analysis, automated contract review, and e-discovery ${ }^{64} \mathrm{JPM}$ organ uses the AI Contract Intelligence (COIN) program, which has been used since June 2017 to interpret commercial loans. Work that previously took 360,000 hours can now be completed in seconds. ${ }^{65}$ Some AI platforms, such as the Kira System, allow lawyers to identify, extract and analyze business information in large volumes of contract data. Because AI can analyze more data, AI can perform better than lawyers in predicting the outcome of disputes and legal proceedings and assisting clients in making decisions. ${ }^{66}$

\section{The Potential for Application of AI for the Legislation}

According to Frank Fagan and Saul Levmore, AI can provide more significant benefits to legislative institutions, especially the House of Representatives, in reducing the potential for errors in the legislative process. ${ }^{67} \mathrm{AI}$ can also assist legal practitioners in analyzing the weaknesses and strengths of legal documents. The law-making and judgments algorithm will take advantage of a model built from a large store of data, allowing for the careful application of rules. Legal experts are also expected to collaborate with $\mathrm{AI}$ in drafting laws and regulations. Collectively, AI can help legal experts apply and create laws that suit society's conditions more optimally. ${ }^{68}$ The use of AI as a tool for the omnibus law legislative body is rational because the omnibus law model tends to have a high complexity level. Also, the collaboration between humans and machines is not new, especially in legal practice. ${ }^{6}$

${ }^{64}$ Harry Surden, "Artificial Intelligence and Law: An Overview" (2019) 35: 4 Georgia State University Law Review 19-22 at 1328-1330.

65 W Bradley Wendel, "The Promise and Limitations of Artificial Intelligence in The Practice of Law" (2019) 72:21 Oklahoma Law Rev 21-49 at 24.

${ }_{66}$ Wang, supra note 69 at 7-8.

67 Fagan \& Levmore, supra note 61 at 1.

68 Wang, supra note 69 at 7.

${ }^{69}$ Fagan \& Levmore, supra note 61 at 3. 


\section{Can Artificial Intelligence Replace Organs?}

There is still debate about the use of AI in formulating laws and policies. ${ }^{70}$ This paper finds that AI cannot immediately replace the Law-forming Organs. Until now, there are no countries that have implemented AI as part of the Law-Making Organ. It is based on several reasons. ${ }^{71}$

First, the legislative product crystallizes norms derived from legal principles, namely values and beliefs that live in a society, applied to that community. ${ }^{72}$ Second, the nature of the legislative product has a relational characteristic of compromise law. The law must be built through compromises on different views in achieving justice built through dialectics so that only the legislative organs can interpret this. ${ }^{73}$ Third, as stated by Stephen Hawking. AI can have a negative impact because, in the short term, AI still requires control from one party. ${ }^{74}$ Thus, it is feared that the resulting Law product will no longer be a legal product containing the people's aspirations but a set of laws based only on specific groups' interests. ${ }^{75}$

The legislative process refers to the Legislative and the Parliament Laws for which AI can be used in the legislative process, starting from the planning process to prepare to level I talks. ${ }^{76}$ Later the output AI can be used as a

70 Cynthia Rudin, "Stop Explaining Black-Box Machine Learning Models for High Stakes Decisions and Use Interpretable Models Instead" (2019) 1: 5 Nature Machine Intelligence $206-215$ at 210.

71 Sihombing \& Syaputra, supra note 4 at 430-431.

72 Winarno Yudho \& Heri Tjandrasari, "Legal Effectiveness in Society" (2017) 17: 1 Journal of Law \& Development 57-63 at 58-60.

73 It can only be obtained through human touch. See: Al Andang L Binawan \& Al Andang, "Tracing the Logic of Legislation"(2005) 10: 3 Jentera Journal at 9.

74 Stephen Hawking et al., Transcendence looks at the implications of artificial intelligencebut are taking $A I$ seriously enough (The Independent, 2014).

75 Sihombing \& Syaputra, supra note 4 at 431.

76 Level I discussion is a further discussion of the draft Law in a plenary session. If the President submits the bill in Level I Talks, it will be the President or minister sent to explain the bill. Meanwhile, if the House of Representatives proposes the bill, further explanation will be made in a commission meeting, joint commission meeting, or special committee meeting. See Article 169 letter a of Law No. 17 of 2014 on Parliament Law. 
consideration to be considered in decision-making at Level II Talks. ${ }^{77}$ AI can only act as a "tool" and not a "determinant" in forming laws. Several AI features can assist their role in the legislation process, namely DocumentReview and Predictive-Analytics.

\section{Document Review}

The omnibus law's preparation is undoubtedly inseparable from scanning legal documents, laws and regulations, and jurisprudence to doctrine. Moreover, the omnibus law contains more substance than ordinary laws. Even done conventionally, it will certainly take much time. Besides that, human errors also often occur. ${ }^{78}$ Using AI, these errors can be reduced, and the process can be carried out more effectively and efficiently. ${ }^{79}$

American company "LawGeex" announces artificial intelligence victory over lawyers in a competition over-analysis of contract terms and issues. ${ }^{80}$ The AI program owned by LawGeex can do logical reasoning based on the available data set. The program can beat lawyers with experience in cognitive and problem-solving abilities. ${ }^{81}$ It proves that AI can do analytical work better than humans. AI can classify and trace the relationship between laws and regulations and then provide detailed reports to users. ${ }^{82}$ Thus, technical

77 Level II Talks are discussions of the bill preceded by an explanation from the leadership, followed by a general view of the factions concerned. In Level II Talks, discussions will be held containing: (a) submission of reports containing the process, opinion of the factions, the opinion of the DPD, as well as the results of the talks that have been conducted at the Level I Talk; (b) each faction and members of the House of Representatives can provide a statement of approval or rejection of the proposed bill, and submitted orally; and (c) the President provides the final opinion conveyed by the minister who has been assigned.

78 Ardila Syakriah \& Budi Sutrisno, "'Fatal' errors found as Job Creation Law enters into force," online: The Jakarta Post <https://www.thejakartapost.com/news/2020/ 11/03/fatal-errors-found -as-job-creation-law-enters-into-force.html>.

79 Rishi Chhatwal et al., Explainable Text Classification in Legal Document Review A Case Study of Explainable Predictive Coding (IEEE, 2018) at 1905.

${ }^{80}$ Oleg Metsker et al., "Russian Court Decisions Data Analysis Using Distributed Computing and Machine Learning to Improve Law-making and Law Enforcement" (2019) 156 Procedia Computer Science 264-273 at 266.

81 Harry Surden, "Computable Contracts" (2012) 46 UCD Law Review 629 at 646.

82 Chhatwal et al., supra note 86 at 1907. 
errors in legislation can be avoided, considering that the recent episodes have shown that there are still some technical errors in the Omnibus Law legislation process. ${ }^{83}$

\section{Predictive Analytics}

With the suitable formulation, AI can proportionally analyze data from various parties, which will later assist legislative bodies in making laws. It is because the law will run effectively if the regulations are measured accurately. ${ }^{84}$ Besides, AI's ability to predict and formulate laws is claimed to be superior to humans. ${ }^{85}$ Because when referring to conventional methods, the law will always be left behind with emerging innovations. The product of the law in the deliberation process takes months to years. Even when a law product has been enacted, often the law cannot accommodate or expires in substance. ${ }^{86}$

Through predictive analytics, AI can briefly and accurately project the implications of law based on the massive data available. ${ }^{87}$ The proof of this claim is the Lex Machina program. The AI program can analyze thousands of patent litigation from various fields. Then generate yield predictions and model a new, better patent design ${ }^{88}$ Besides, after the bill is uploaded on the legislative body's website, the public can analyze the bill's origin more comprehensively; AI can cluster various indicators precisely in a relatively short time. ${ }^{89}$

83 Kuswandi, "Jawapos.com," (November 03, 2020), online: Creation Government Admits Technical Errors in the JobLaw <https://www.jawapos.com/nasional/03/11/2020/ pemerintah-akui-kesalahan-teknis -in-uu-copyright-work />.

${ }^{84}$ Fagan \& Levmore, supra note 61 at 1.

85 Ibid at 31.

86 JA Barefoot, "Disrupting Fintech Law" (2015) 18: 2 Fintech Law Reporter 1-18 at 10.

87 Surden, supra note 71 at 1314-1316.

${ }^{88}$ John O McGinnis \& Russell G Pearce, "The Great Disruption: How Machine Intelligence Will Transform the Role of Lawyers in the Delivery of Legal Services" (2019) Actual Problems in Economics \& Law at 3053.

89 Ibid at 3051-3055. 
AI can also make decisions faster than humans. ${ }^{90}$ In this case, AI can make risk analysis more effective and efficient. ${ }^{91}$ Besides, this AI can analyze various factors and can develop itself from time to time based on the ongoing learning process. ${ }^{92}$ AI capabilities are considered significant help to legislators' performance in creating more effective and efficient legal products. ${ }^{93}$ With the use of AI technology in the legislative process, it is expected that each draft of the omnibus law can show a more comprehensive basis for consideration. In this case, this does not mean that AI will completely replace humans because the combination of humans and AI will be superior to relying on only one of them. ${ }^{94} \mathrm{AI}$ and humans can collaborate to create a better life order through participatory and measurable legal formulation.

\section{CONCLUSION}

Economic considerations are the government's main foothold in implementing the omnibus law model. Overlapping laws and regulations are a significant obstacle in increasing the rate of economic growth in Indonesia. The application of the omnibus law model is also considered a practical solution. On the other hand, the omnibus law model is considered a pragmatic and less democratic law practice. The inadequacy of the legislative mechanism and the House of Representatives' relatively fast deliberation has implications for decreasing public participation. AI can be considered an effort to optimize omnibus law legislation's effectiveness and efficiency. AI's role is only a "tool" and not a "determinant" in omnibus law legislation. Besides, so far, no country has used $\mathrm{AI}$ in formulating laws and policies.

90 Denindah Olivia, "Legal Aspects of Artificial Intelligence on Automated Decision-Making in Indonesia" (2020) 7: 3 Lentera Hukum 301 at 304.

91 Gang Kou et al., "Machine Learning Methods for Systemic Risk Analysis in Financial Sectors" (2019) 25: 5 Technological and Economic Development of Economy 716-742 at 725-726.

92 Peter Flach, Machine Learning: The Art and Science of Algorithms That Make Sense of Data (London: Cambridge University Press, 2012) at 3.

93 Harry Surden, "Machine Learning and Law" (2014) 89 Washington Law Review 87115 at 105.

94 Fagan \& Levmore, supra note 61 at 5. 
As a follow-up to AI application in legislation, this paper recommends forming a particular institution that focuses on legislation formation. The Organization recommends it for Economic Co-operation and Development, such as the National Regulatory Control Council in Germany and The Administrative Board for Administrative Burdens in the Netherlands. Later this institution will be responsible for developing AI to optimize the omnibus law legislation in Indonesia.

\section{REFERENCES}

Amin, Rizal Irvan, "Omnibus Law Between Desiderata and Reality" (2020) 15: 2 Journal of Ocean Justice Law 190-209.

Anggono, Bayu Dwi, "Omnibus Law as a Law Formation Technique: Adoption Opportunities and Challenges in the Indonesian Legislative System" (2020) 9: 1 Rechtsvinding.

Barefoot, JA, "Disrupting Fintech Law" (2015) 18: 2 Fintech Law Reporter $1-18$.

Binawan, Al Andang L \& Al Andang, "Tracing the Logic of Legislation" (2005) 10: 3 Jentera Journal.

Buana, Mirza Satria, "Measuring the Concept of Omnibus Law and Consolidation Law for Harmonization of Indonesian Legislation: A Comparative Approach to Constitutional Law" (2017).

Center for Indonesian Law and Policy Studies (PSHK), Study of regulatory reform in Indonesia: issues and strategies for handling them (2019).

Central Bureau of Statistics, "August 2020: Open Unemployment Rate (TPT) of 7.07 percent", (2020), online: <https://www.bps.go.id/ pressrelease/2020/11/05/1673/ august-2020 - open-unemploymentrate - tpt - by-7-07-percent.html>.

Central Bureau of Statistics, "2019 Indonesian Youth Statistics" (2019) Jakarta: Central Bureau of Statistics.

Central Bureau of Statistics, Indonesian National Income 2015-2019 (2020). 
Čerka, Paulius, Jurgita Grigienė \& Gintarè Sirbikyte, "Liability for damages caused by artificial intelligence" (2015) 31: 3 Computer Law \& Security Review 376-389.

Chhatwal, Rishi, et al., Explainable Text Classification in Legal Document Review A Case Study of Explainable Predictive Coding (IEEE, 2018).

Chui, Wing Hong \& Mike McConville, Research methods for law (Edinburgh University Press Edinburgh, 2007).

Djasmani, H Yacob, "Law as a Social Engineering Tool in Legal Practice in Indonesia" (2011) 40: 3 Legal Problems 365-374.

Donahue, Lauri, "A Primer on Using Artificial Intelligence in the Legal Profession” January 03, 2018.

Fagan, Frank \& Saul Levmore, "The Impact of Artificial Intelligence on Rules, Standards, and Judicial Discretion" (2019) 93 Southern California Law Review 1.

Fenwick, Mark, Wulf A Kaal \& Erik PM Vermeulen, "Regulation Tomorrow: What Happens When Technology Is Faster Than the Law?" (2016) SSRN Journal, online: <http://www.ssrn.com/abstract= 2834531>.

Firdaus, Fahmi Ramadhan, "Prevention of Legislative Corruption through Strengthening Public Participation in the Process of Forming a Law" (2020) 17: 3 Indonesian Legislation Journal 282-293.

Flach, Peter, Machine Learning: The Art and Science of Algorithms That Make Sense of Data (London: Cambridge University Press, 2012).

Hawking, Stephen et al., Transcendence look at the implications of artificial intelligence-but are taking AI seriously enough (The Independent, 2014).

Indonesian Center for Law \& Policy Studies, "Discussion of the Omnibus Bill on Job Creation Directly to the Panja: Trimmed Participation, Regulations Willed", (20 April 2020), online: pshk.or.id <https://pshk.or.id/publikasi/discussion-omnibus-copyright-workdirect-to-panja-participation-trimmed-order-cutting-edge $/>$. 
Kaal, Wulf A, "Dynamic regulation for innovation" (2016) Perspectives in Law, Business \& Innovation (Mark Fenwick, Wulf A Kaal, Toshiyuki Kono \& Erik PM Vermeulen eds), New York Springer (2016) 16-22.

Kemp, Richard, "Legal aspects of artificial intelligence" (2016) 2 Kemp IT Law.

Komnas HAM, "Komnas HAM: Unaccountable and Participatory Omnibus Law Preparation," (January 31, 2020), online: National Commission on Human Rights-KOMNAS HAM <https:// www.komnasham.go.id/index.php/ news / 2020/1/31/1319 / Komnasham-drafting-omnibus-law-not-accountable-and-participatory.html> .

Kompas, "Complete Text of President Joko Widodo's Speech in the Inauguration of the 2019-2024 Period - JEO Kompas.com", online: $<$ https://nasional.kompas.com/jeo/naskah-1 Lengkap-pidato-presidenjoko-widodo-dalam - inauguration-period-2019-2024>.

Kou, Gang, et al., "Machine Learning Methods for Systemic Risk Analysis in Financial Sectors" (2019) 25: 5 Technological and Economic Development of Economy 716-742.

Kristiyanto, Eko Noer, "The Urgency of the Omnibus Law in the Acceleration of Regulatory Reform in a Progressive Legal Perspective" (2020) 20: 2 De Jure Legal Research Journal 233-244.

Krutz, Glen S \& Samuel C Patterson, Hitching a ride: Omnibus legislating in the US Congress (Ohio State University Press, 2001).

Kuswandi, "Jawapos.com," (November 03, 2020), online: Government Admits Technical Errors in the Job Creation Law $<$ https://www.jawapos.com/nasional/03/11/2020/pemerintah-akuikesalahan-teknis -in-uu-copyright-work / >.

Maria Farida Indrati, Responding to Omnibus Law as the Sweep of the Universe Law (Djokosoetono Research Center and Department of State Administrative Law, Universitas Indonesia, 2020).

Marr, Bernard, "How AI And Machine Learning Are Transforming Law Firms And The Legal Sector," online: Forbes <https://www.forbes. 
com/sites/bernardmarr/2018/05/23/how-ai-and-machine-learningare-transforming-law-firms-and-the-legal-sector/> .

Massicotte, Louis, "Omnibus Law in Theory and Practice" (2013) 36: 1 Canadian Parliamentary Review.

McGinnis, John O \& Russell G Pearce, "The Great Disruption: How machine intelligence will transform the role of lawyers in the delivery of legal services" (2019) Actual Problems in Economics \& Law.

MD, Mahfud, "Constitution and Law in Controversial Issues (2010) Rajawali Pers, Jakarta.

Metsker, Oleg, et al., "Russian Court Decisions Data Analysis Using Distributed Computing and Machine Learning to Improve Lawmaking and Law Enforcement" (2019) 156 Procedia Computer Science 264-273.

Mikhaylov, Slava Jankin, Marc Esteve \& Averill Campion, "Artificial intelligence for the public sector: opportunities and challenges of crosssector collaboration" (2018) 376: 2128 Philosophical Transactions of the Royal Society A: Mathematical, Physical and Engineering Sciences, online: <https://royalsocietypublishing.org/doi/full/10.1098/rsta.2017.0357>.

Ministry of Home Affairs of the Republic of Indonesia, "Kemendagri Officially Announces 3,143 Perda Canceled", (June 21, 2016), online: Cabinet Secretariat of the Republic of Indonesia <https://setkab.go.id/ kemendagri-resmi- anno-3-143-perda -what-canceled />.

Ministry of National Development Planning, "National Strategy for Regulatory Reform: Realizing Simple and Orderly Regulations” (2015) Ministry of National Development Planning / National Development Planning Agency.

Ministry of National Development Planning, "National Medium Term Development Plan 2015-2019" (2019) National Medium Term Development Plan 2020-2024.

National Development Planning Agency, "Ministry of National Development Planning," online: <https://www.bappenas.go.id/id/ 
berita-dan-siaran-pers/rencana-pembangunan-jangka-menengahnasional-rpjmn-2020 -2024 />.

Olivia, Denindah, "Legal Aspects of Artificial Intelligence on Automated Decision-Making in Indonesia” (2020) 7: 3 Lentera Hukum 301.

Organization For Economic Co-operation and Development (OECD), "Better Regulation in the Netherlands" (2009) European Commission 112.

Pagallo, Ugo, The Laws of Robots (Dordrecht: Springer Netherlands, 2013).

Purawan, Akhmad Adi, "Corruption of Legislation in the Formation of Legislative Regulations" (2014) 3: 3 Rechtsvinding: Media of National Law Development 347-363.

Putri, Cantika Adinda, "DPR Top! 1,200 Articles of Omnibus Law Completed Through 64 Meetings", online: news <https://www. cnbcindonesia.com/news/20201006154706-4-192288/dpr-top-1200pasal-omnibus-law-sel finished-lewat-64 -times meetings $>$.

Razy, Muhammad Fakhrur \& Muhammad Fedryansyah, "Conflict of Civil Society Movement and Government in the Process of Drafting the Omnibus Law Bill" (2020) 2: 2 Collaborative Journal of Conflict Resolution 74-85.

Rudin, Cynthia, "Stop explaining black-box machine learning models for high stakes decisions and use interpretable models instead" (2019) 1: 5 Nature Machine Intelligence 206-215.

Sagama, Suwardi, "Analysis of the Concept of Justice, Legal Certainty and Benefit in Environmental Management" (2016) 15: 1 Mazahib 20-41.

Schwab, Klaus, "The Global Competitiveness Report 2019" (2019) World Economic Forum.

Sihombing, Eka NAM \& Muhammad Yusrizal Adi Syaputra, "Implementation of the Use of Artificial Intelligence in Forming Regional Regulations" (2020) 14: 3 Scientific Journal of Legal Policy 419-434. 
Surden, Harry, "Artificial intelligence and law: An overview" (2019) 35: 4 Georgia State University Law Review 19-22.

__ _Computable Contracts" (2012) 46 UCD L Rev 629.

—_, "Machine learning and law" (2014) 89 Wash L Rev 87-115.

Suriadinata, Vincent, "Formulation of Laws in the Investment Sector: Study of the Formation of Omnibus Law in Indonesia" (2019) 4: 1 Reflection on Law: Journal of Legal Studies 115-132.

Syakriah, Ardila \& Budi Sutrisno, "'Fatal' errors found as Job Creation Law enters into force," online: The Jakarta Post <https://www. thejakartapost.com/news/2020/11/03/fatal-errors- found-as-jobcreation-law-enters-into-force.html>.

Ulum, Muhammad Bahrul, "Indonesian Democracy and Political Parties After Twenty Years of Reformation: A Contextual Analysis" (2020) 10:1 Indonesia Law Review.

Umbara, Deni, Jum Hermanto \& Franky Ariyadi, "Community Pro-Contra Project For The Presence Of The Omnibus Law Bill In Legal Sociology Perspective" (2020) 4: 2 Legal Standing: Jurnal Ilmu Hukum 168-173.

Vereinte Nationen, ed, United Nations Convention on the Use of Electronic Communications in International Contracts (New York: United Nations, 2007).

Wang, Ran, "Legal technology in contemporary USA and China" (2020) 39 Computer Law \& Security Review.

Wendel, W Bradley, "The Promise and Limitations of Artificial Intelligence in The Practice of Law" (2019) 72:21 Oklahoma Law Rev 21-49.

World Bank (Washington, District of Columbia), ed, Doing business 2020, Doing business (Washington: World Bank Group, 2019).

Yudho, Winarno \& Heri Tjandrasari, "Legal Effectiveness in Society" (2017) 17: 1 Journal of Law \& Development 57-63. 
103 | Indonesian Journal of Law and Society

Yudoprakoso, Paulus Wisnu, "Artificial Intelligence as a Tool for the Formulation of Laws in Facing the Industrial Revolution 4.0 in Indonesia" (2019) 1: 1 Indonesian Legal Symposium 450-461. 
104 | Optimizing Omnibus Law in Indonesia: A Legal Enquiry

This page intentionally left blank 